2013-6

\title{
Environmental Consequences of a Power Plant Shut-Down: A Three-Dimensional Water Quality Model of Dublin Bay
}

\author{
Zeinab Bedri \\ Technological University Dublin, zeinab.bedri@tudublin.ie \\ Michael Bruen \\ University College Dublin, michael.bruen@ucd.ie \\ Aodh Dowley \\ University College Dublin
}

See next page for additional authors

Follow this and additional works at: https://arrow.tudublin.ie/engschcivart

Part of the Civil Engineering Commons, and the Environmental Engineering Commons

\section{Recommended Citation}

Bedri, Z. et al. (2013)Environmental consequences of a power plant shut-down: A three-dimensional water quality model of Dublin Bay,Marine Pollution Bulletin, Vol. 71, No. 1-2, pp. 117-128. doi.org/10.1016/ j.marpolbul.2013.03.025

This Article is brought to you for free and open access by the School of Civil and Structural Engineering at ARROW@TU Dublin. It has been accepted for inclusion in Articles by an authorized administrator of ARROW@TU Dublin. For more information, please contact arrow.admin@tudublin.ie, aisling.coyne@tudublin.ie, gerard.connolly@tudublin.ie.

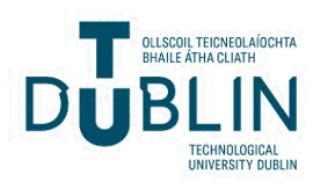




\section{Authors}

Zeinab Bedri, Michael Bruen, Aodh Dowley, and Barthelomew Masterson

This article is available at ARROW@TU Dublin: https://arrow.tudublin.ie/engschcivart/84 


\section{AUTHOR QUERY FORM}

\begin{tabular}{|l|l|l|}
\hline \multicolumn{1}{|c|}{} & Journal: MPB & Please e-mail or fax your responses and any corrections to: \\
$\begin{array}{l}\text { E } \\
\text { ELSEVIER }\end{array}$ & Article Number: 5641 & Fax: +31204852799 \\
\hline
\end{tabular}

Dear Author,

Please check your proof carefully and mark all corrections at the appropriate place in the proof (e.g., by using on-screen annotation in the PDF file) or compile them in a separate list. Note: if you opt to annotate the file with software other than Adobe Reader then please also highlight the appropriate place in the PDF file. To ensure fast publication of your paper please return your corrections within 48 hours.

For correction or revision of any artwork, please consult http://www.elsevier.com/artworkinstructions.

Any queries or remarks that have arisen during the processing of your manuscript are listed below and highlighted by flags in the proof. Click on the ' $Q$ ' link to go to the location in the proof.

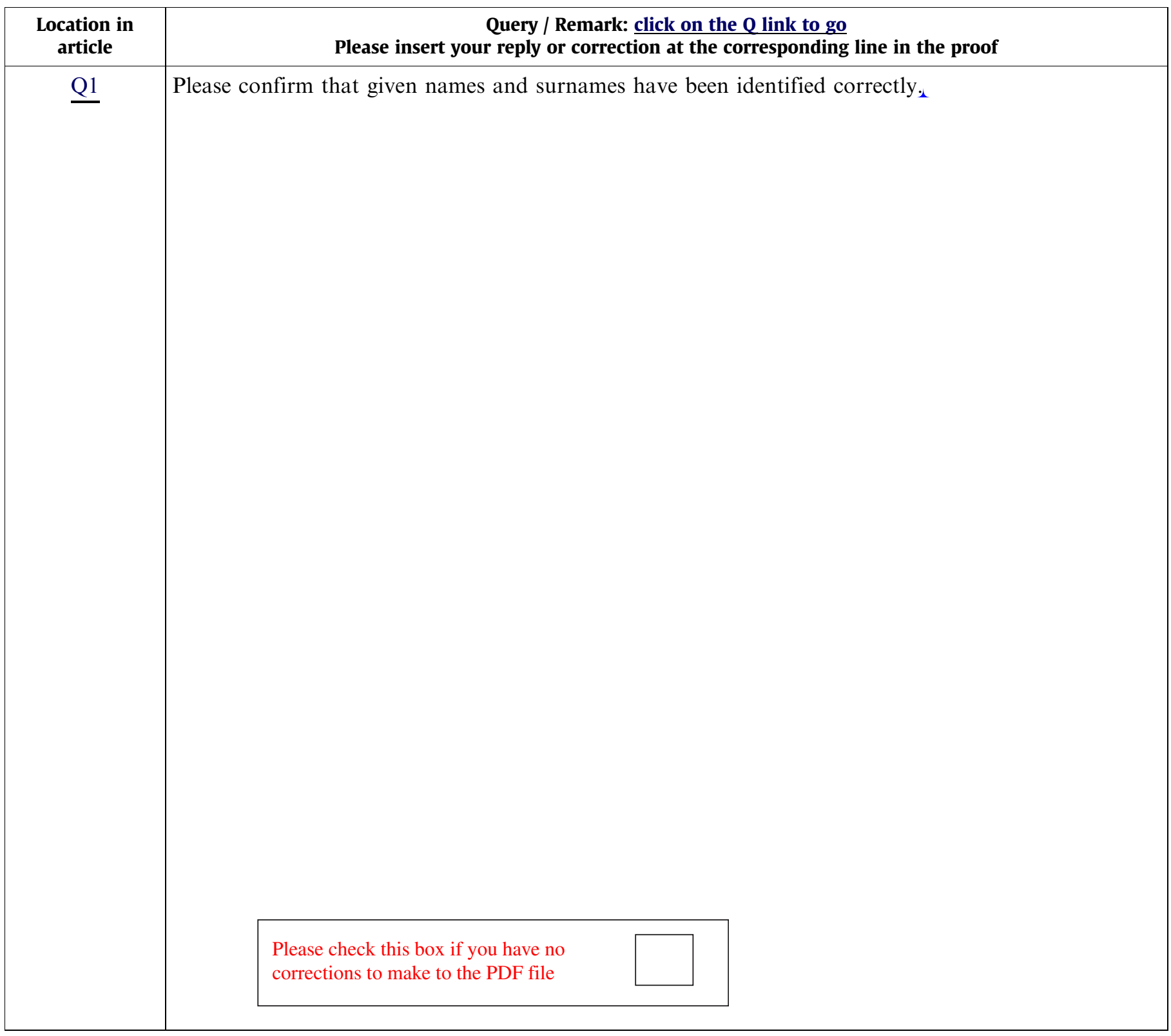

Thank you for your assistance. 


\section{Highlights}

- A hydro-environmental model investigated the consequences of closing a power plant. • Model simulated water quality for three scenarios before and after closing the plant. • Dilution scenario gave better water quality results than direct discharges scenario. • Direct discharges scenario showed an increased stratification of the estuary waters. 


\title{
Environmental consequences of a power plant shut-down: A three-dimensional water quality model of Dublin Bay
}

\author{
${ }^{a}$ Centre for Water Resources Research, University College Dublin, Newstead Building, Belfield, Dublin 4, Ireland \\ $6 \quad{ }^{\mathrm{b}}$ Conway Institute of Biomolecular and Biomedical Research, University College Dublin, Belfield, Dublin 4, Ireland
}

\section{A R T I C L E I N F O}

\section{Keywords:}

Thermal discharges

Stratification

Three-dimensional model

Bathing water quality

Hydrodynamics

Escherichia coli

\begin{abstract}
A B S T R A C T
A hydro-environmental model is used to investigate the effect of cessation of thermal discharges from a power plant on the bathing water quality of Dublin Bay. Before closing down, cooling water from the plant was mixed with sewage effluent prior to its discharge, creating a warmer, less-saline buoyant pollutant plume that adversely affects the water quality of Dublin Bay. The model, calibrated to data from the period prior to the power-plant shut-down (Scenario1), assessed the water quality following its shut-down under two scenarios; (i) Scenario2: continued abstraction of water to dilute sewage effluents before discharge, and (ii) Scnenario3: sewage effluents are discharged directly into the Bay. Comparison between scenarios was based on distribution of Escherichia coli (E. coli), a main bathing quality indicator. Scenarios1 and 2, showed almost similar E. coli distribution patterns while Scenario3 displayed significantly higher $E$. coli concentrations due to the increased stratification caused by the lack of prior dilution. (c) 2013 Published by Elsevier Ltd.
\end{abstract}

\section{Introduction}

Thermal discharges into marine waters may cause serious perturbations in the natural marine environment. The change in the temperature regime and the associated reduction in the saturation levels of dissolved oxygen both adversely impact on aquatic and benthic communities (e.g.Choi et al., 2012; Chuang et al., 2009; Martinez-Arroyo et al., 2000; Syed Mohamed et al., 2010).

Another major environmental consequence is the increased stratification of receiving waters (e.g. Jiang et al., 2003; Kolluru et al., 2003; Lowe et al., 2009; Wu et al., 2001). These can profoundly limit the assimilation of polluting discharges by preventing the mixing between the warmer upper levels and the cooler water underneath. Moreover, if pollutants are added to the flow with, or subsequent to, the thermal discharge the pollution will, nearly invariably, remain in the upper, warmer layer (Ellis, 1989). The presence of pollutants in the discharged cooling water has been reported in a number of studies (see Langford, 1990). These include chlorine (Fernandez Torres and Ruiz Bevia, 2012; Ma et al., 1998; Marcos et al., 1997), heavy metals (Abdul-Wahab and Jupp, 2009; Baba et al., 2003; Gong et al., 2010), and flue-gas desulpherisation effluents (Liu et al., 2003; Mohsen, 2004; Van Den Hende et al., 2011).

Discharging municipal wastes to the same receiving waters may considerably exacerbate the stratification. The fate and transport of

\footnotetext{
* Corresponding author. Tel.: +353 1716 3228; fax: +353 17163297.

E-mail address: zeinab.bedri@ucd.ie (Z. Bedri).
}

pollutants from sewage works into coastal waters is welldocumented (e.g. Bouvy et al., 2008; Dhage et al., 2006; Mozetix et al., 2008; Nicholson et al., 2011; Vijay et al., 2010), however there is a lack in literature on the interaction between municipal sewage effluents and thermal discharges from power generation plants, when both occur together, despite their importance as highlighted by Bedri et al. (2011). The worst case scenario of such interaction occurs when municipal sewage effluents are directly mixed with cooling water prior to discharge. This was typically the case in the Liffey Estuary, Dublin which has received combined discharges from Ireland's largest power generation station at Poolbeg and Ringsend sewage treatment plant creating a warm, lesssaline layer that remained buoyant on the water surface. The effect of the combined discharge is two-fold; (i) the heated discharges reduces oxygen levels in the Estuary (O'Boyle et al., 2009) which in turn negatively impacts on the estuarine fish species, some of which are of international conservation importance (Hartnett et al., 2011; Jovanovic et al., 2007) and are listed in the EU Habitats Directive 92/43/EEC (EEC, 1992), and (ii) the buoyant sewage plume affects the compliance of waters of Dublin Bay (into which the Liffey Estuary flows) to the microbial standards of the Bathing Water Directive 2006/7/EC (EC, 2006) at beaches of high recreational and national importance (ERU, 1992; Wilson et al., 2002).

In 2010, the Poolbeg power generation plant was closed as part of a competition agreement with the Irish Energy Regulators to facilitate the introduction of additional energy providers to the Irish market. As a result the thermal discharges into the estuary have ceased and this is expected to alleviate the stress on the

0025-326X/\$ - see front matter (c) 2013 Published by Elsevier Ltd http://dx.doi.org/10.1016/j.marpolbul.2013.03.025 
aquatic life in the Estuary. However, due to the continued municipal sewage discharge from Ringsend the effect of the shut-down of the power plant on the water quality in the estuary and inner bay requires investigation. The available annual records of microbial water quality monitoring data are not sufficient to investigate this question, because (i) the data records consists of discrete samples collected only during the bathing season (May-September); and (ii) lack of long term data for the period after the Poolbeg plant shutdown. Therefore there is a need to use a numerical model to study the effect of the cessation of thermal discharges on the water quality of Dublin Bay.

Numerical models have become valuable tools for studying the effect of discharges into the marine environment. These models vary in level of complexity and modelling approaches as they can be length scale and entrainment models (e.g. Daviero and Roberts, 2006; Donker and Jirka, 2007; Frick et al., 2003; Jirka, 2004, 2006), or particle tracking models (e.g. Havens et al., 2010; Korotenko et al., 2004; Miyake et al., 2009; Perianez and Caravaca, 2010), or hydrodynamic models (e.g. Casulli and Walters, 2000; Falconer, 1986; Hervouet, 2007; Lesser et al., 2004; Warren and Bach, 1992). While the first two types are most suitable for representing the mixing processes in the vicinity of the discharge outfalls (nearfield), hydrodynamics models allow for accurate and robust representation of processes in both near- and far-fields regions of the discharge outfalls. Hydrodynamic models can be two-dimensional (depth-averaged) for well-mixed conditions (e.g. Abbaspour et al., 2005; Cea et al., 2011; Kashefipour et al., 2006) or three-dimensional where vertical mixing is absent/limited in the vicinity of the outfall due to density variation (e.g. Bedri et al., 2011; Kolluru et al., 2003; Liu et al., 2007; Signell et al., 2000). Hence a threedimensional hydrodynamic model is needed in the current case study to represent the density-driven flow processes.

The three-dimensional model, TELEMAC-3D (EDF, 1997; Hervouet, 2007), is used in this study to simulate the stratification status, in the estuary before and after the power-plant shut-down, and its subsequent effect on the transport and fate of pollutants. The model was first calibrated based on measured hydrodynamic and water quality data from the period before the cessation of thermal discharges (Scenario1). Then, the calibrated model is used to assess the bathing water quality in the inner Bay for the period following the shut-down of the power generation plant and continued sewage discharges, under two likely scenarios: (i) do nothing scenario where sewage effluent is discharged directly into the Estuary, and (ii) dilution scenario: where a continued abstraction of estuary water is used to dilute sewage effluent before being released into the estuary.

In this paper, Section 2 describes the study area and the main environmental pressures on its water quality. The main equations of TELEMAC-3D are outlined in Section 3, followed by a description of the configuration of the model to represent the study area and choice of the modelling scenarios to study. The modelling results are presented in Sections 5 and 6, and the conclusions drawn from these results are summarised in Section 7.

\section{Case study}

The study area comprises the Liffey Estuary and Dublin Bay, on the east coast of Ireland. Dublin Bay, bounded by the rocky headlands of Howth Head and Dalkey on its Eastern side (Fig. 1), is about $10 \mathrm{~km}$ wide at its mouth and has an area of about $100 \mathrm{~km}^{2}$. The bed of the bay slopes gently seawards (to the East) from low water to a depth of about $12 \mathrm{~m}$, thereafter it slopes more steeply to reach 20-25 m approximately on the line between the headlands. The Bay receives freshwater inflows from the Liffey River.
The Liffey Estuary covers a wide area of $5 \mathrm{~km}^{2}$ and is narrowed down at its outlet by the North and South Walls. The Estuary is macro-tidal (Dyer, 1973) having a mean tidal range of $2.75 \mathrm{~m}$ and average mean spring and neap tides of $3.6 \mathrm{~m}$ and $1.9 \mathrm{~m}$ respectively (Mansfield, 1992).

The main freshwater inflow into the Estuary is from the Liffey River which flows through the City of Dublin. This is regulated by an upstream hydro-electric plant and dam resulting in a smoothly varying inflow of freshwater (approx. $12.42 \mathrm{~m}^{3} / \mathrm{s}$ ) with considerable attenuation of its floods. The river is tidal all the way through the City of Dublin up to distance $10.5 \mathrm{~km}$ upstream of Poolbeg.

Two main structures lie, close together, on the south bank of the Liffey Estuary: the Electricity Supply Board (ESB) power generation plant at Poolbeg and Ringsend Sewage Treatment Works. The ESB power generating facility at Poolbeg, Dublin (Fig. 2) was, when working, the largest gas and oil plant in the country with an installed capacity of $1020 \mathrm{MW}$.

The steam-driven generating equipment required 2.1 million cubic metres a day of once-through seawater to cool the heat exchanger and discharged the heated water into the estuary at a temperature of $7-9{ }^{\circ} \mathrm{C}$ above ambient. Before being discharged (approximately $120 \mathrm{~m}$ upstream of the discharge weir), the cooling water from this plant was mixed with the sewage effluent from Ringsend Treatment Works creating a warm and less saline pollutant plume that remains buoyant on the water surface in the Estuary. The ESB power plant was closed down in 2010 following an agreement between the ESB and the Irish Energy Regulators.

In 2003, Ringsend (STW) was expanded to cater for a population equivalent of 1.7 million. A $10.5 \mathrm{~km}$ submarine pipe (Fig. 2) was constructed to bring wastewater from North Dublin to Ringsend. The plant includes primary, secondary treatments, and Ultra-Violet disinfection (used only during the bathing season) to help meet EU Bathing Water Directive (2006/7/EC) standards for microbial water quality indicators (Escherichia coli (E. coli) and Intestinal Enterococci (IE)) at recreational beaches on the north and south inner Bay (e.g. Dollymount, Sandymount and Merrion Strand).

In the past, prior to the Poolbeg plant shut-down, a number of ad hoc water quality surveys were conducted (e.g. Bedri, 2007; Crisp, 1976; DCC, 2002, 2003; Mansfield, 1992) to monitor water quality parameters including $\hat{E}$. coli and IE in the Liffey Estuary and Dublin Bay. At the present, the only on-going monitoring programme is that carried out by Dublin City Council (DCC) during the months of May-September at bathing sites to test their compliance with the E. coli and IE standards of the EU Bathing Water Directive (2006/7/EC). However, the E. coli and IE data record is insufficiently detailed to deduce any changes in the microbial water quality trends after the shut-down of the power plant at Poolbeg and therefore it has not been included in the current study.

\section{TELEMAC-3D model}

The TELEMAC-3D model, developed by the National Laboratory of Hydraulics and Environment of Electricité de France, was selected for the study because it includes the following essential features: (1) the use of a finite element unstructured grid which allows selective refinement of the mesh at key locations in the domain and boundary fitting (sigma transformation) method for vertical discretisation; (2) density-driven hydrodynamics allowing for a robust treatment of the stratified plume, essential for this study; (3) heat exchange with the atmosphere; (4) the availability of a range of options for vertical turbulence modelling including the facility to incorporate a user-defined subroutine which has been used in the current study to fine tune the vertical temperature and salinity profiles to measurements; (5) the provision of a 


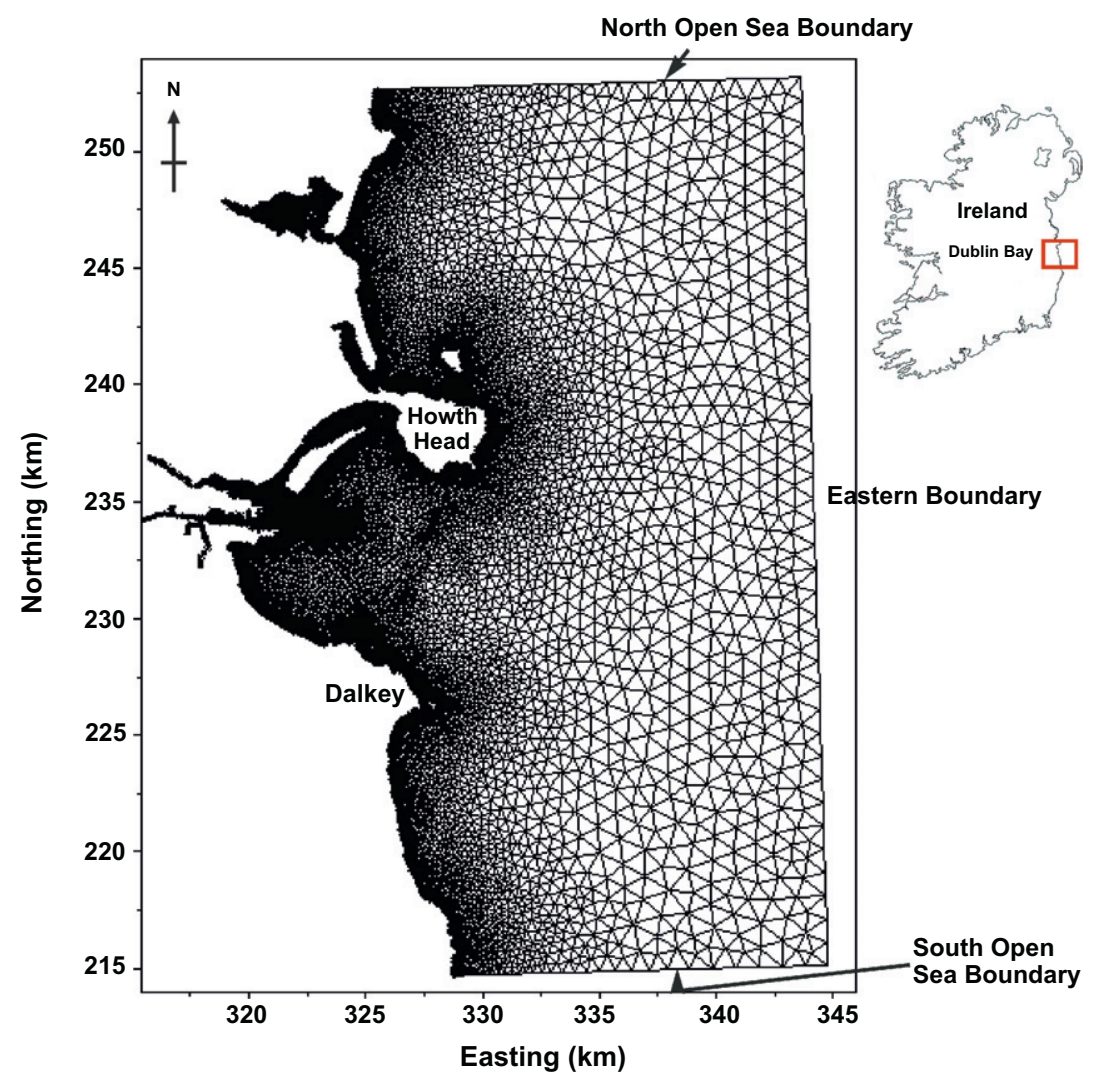

Fig. 1. Study area: model domain and mesh.

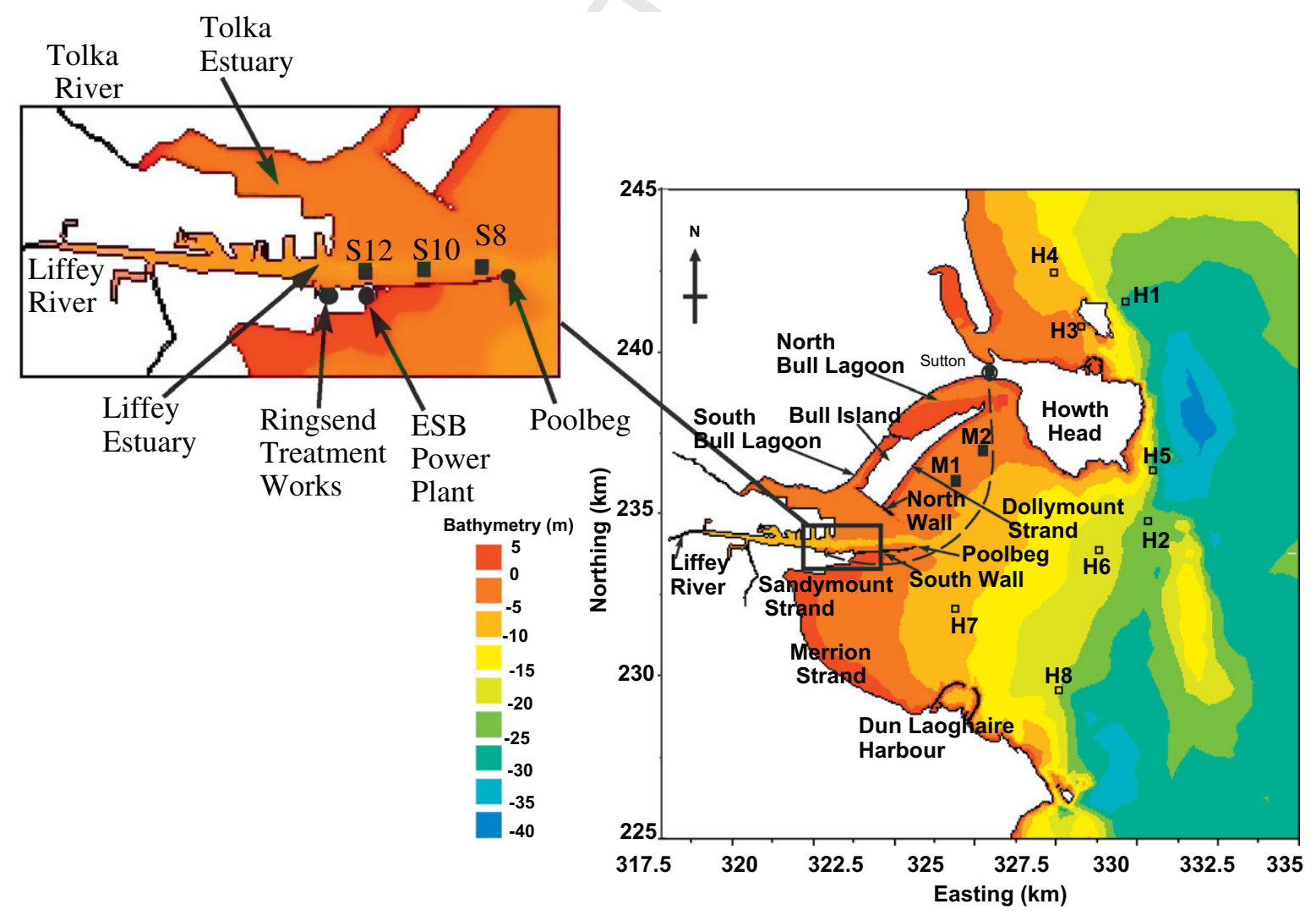

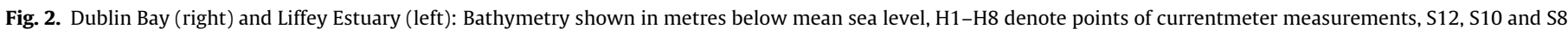
are points of temperature and salinity measurements, and M1 and M2 are water quality measurement points.

Please cite this article in press as: Bedri, Z., et al. Environmental consequences of a power plant shut-down: A three-dimensional water quality model of Dublin Bay. Mar. Pollut. Bull. (2013), http://dx.doi.org/10.1016/j.marpolbul.2013.03.025 
subroutine for the modelling of source/sink of tracers which has been used in this study to incorporate a time- and space-varying decay rate of $E$. coli (the first published attempt to incorporate a time- and space-varying E. coli decay rate in TELEMAC-3D).

\subsection{Flow hydrodynamics}

The finite element model TELEMAC-3D (Hervouet, 2007) solves the 3D Reynolds-Averaged Navier-Stokes (RANS) equations for free-surface flow environments (e.g. estuaries, seas, streams, lakes, and coastal waters). The current study applies the hydrostatic version of TELEMAC-3D which reduces the equations to:

$$
\frac{\partial}{\partial x}(u)+\frac{\partial}{\partial y}(v)+\frac{\partial}{\partial z}(w)=0
$$

$$
\begin{aligned}
\frac{\partial}{\partial t}(u) & +u \frac{\partial}{\partial x}(u)+v \frac{\partial}{\partial y}(u)+w \frac{\partial}{\partial z}(u) \\
= & -\frac{1}{\rho_{o}} \frac{\partial}{\partial x}(p)+\frac{\partial}{\partial x}\left(v_{H} \frac{\partial}{\partial x}(u)\right)+\frac{\partial}{\partial y}\left(v_{H} \frac{\partial}{\partial y}(u)\right) \\
& +\frac{\partial}{\partial z}\left(v_{z} \frac{\partial}{\partial z}(u)\right)+S_{x}
\end{aligned}
$$

$$
\begin{aligned}
\frac{\partial}{\partial t}(v) & +u \frac{\partial}{\partial x}(v)+v \frac{\partial}{\partial y}(v)+w \frac{\partial}{\partial z}(v) \\
= & -\frac{1}{\rho_{o}} \frac{\partial}{\partial y}(p)+\frac{\partial}{\partial x}\left(v_{H} \frac{\partial}{\partial x}(v)\right)+\frac{\partial}{\partial y}\left(v_{H} \frac{\partial}{\partial y}(v)\right) \\
& +\frac{\partial}{\partial z}\left(v_{z} \frac{\partial}{\partial z}(v)\right)+S_{y}
\end{aligned}
$$

$p=p_{a t m}+\rho_{o} g(Z-z)+\rho_{o} g \int_{z}^{Z} \frac{\Delta \rho}{\rho_{o}} d z$

where $x, y$, and $z$ are the Cartesian axes, $u, v$, and $w$ are the velocity components in the $x, y$, and $z$ directions $\left(\mathrm{m} \mathrm{s}^{-1}\right), t$ is the time in seconds, $Z$ is the water surface elevation $(\mathrm{m}), p$ is the pressure $\left(\mathrm{N} \mathrm{m}_{\lambda}^{-2}\right)$, $\rho_{o}$ and $\Delta \rho$ are the reference density and variation in density respectively $\left(\mathrm{kg} \mathrm{m}^{-3}\right), S_{x}$ and $S_{y}$ are velocity source terms (wind, Coriolis force, etc.) ( $\left.\mathrm{m} \mathrm{s}^{-2}\right), v_{H}$ and $v_{Z}$ are the eddy viscosity in the horizontal and vertical direction respectively $\left(\mathrm{m}^{2} \mathrm{~s}^{-1}\right)$ resolved through turbulence modelling in Section 3.3 below.

\subsection{Transport of Tracers}

The mass-balance equation below (Eq. (5)) simulates the temporal and the spatial variations of: (i) active tracers (those that influence water density; in this study, these are temperature and salinity), and (ii) passive tracers ( $E$. coli in the current study).

$$
\begin{aligned}
\frac{\partial}{\partial t} & (C)+u \frac{\partial}{\partial x}(C)+v \frac{\partial}{\partial y}(C)+w \frac{\partial}{\partial z}(C) \\
& =\frac{\partial}{\partial x}\left(K_{H} \frac{\partial}{\partial x}(C)\right)+\frac{\partial}{\partial y}\left(K_{H} \frac{\partial}{\partial y}(C)\right)+\frac{\partial}{\partial z}\left(K_{Z} \frac{\partial}{\partial z}(C)\right)+Q_{c}
\end{aligned}
$$

$C$ is the concentration of tracer, $Q_{C}$ is the tracer source or sink (e.g. decay of E. coli below), and $K_{H}$ and $K_{Z}$ are the eddy diffusivity coefficients in the horizontal and vertical directions respectively $\left(\mathrm{m}^{2} \mathrm{~s}^{-1}\right)$ resolved by the turbulence models (Section 3.3).

The values of temperature and salinity calculated for any point in space or time are used to compute the water density at that point using the state equation (Hervouet, 2007):

$\rho=\rho_{o}\left[1-\left[\left(T-T_{o}\right)^{2} \times 7-750 S\right] \times 10^{-6}\right]$

With $\rho_{o}=999.972 \mathrm{~kg} \mathrm{~m}^{-3}$ (reference density), $T_{o}=4{ }^{\circ} \mathrm{C}$ (reference temperature), and $S$ is the salinity measured in Practical Salinity
Units (PSUs). The density variation in the flow field $(\Delta \rho / \rho$ in Eq. (4)) is hence calculated.

While the tracer mass-balance equation (Eq. (5)) readily resolves advection and dispersion of tracers, the process of decay/die-off of $E$. coli needs to be incorporated via the source/sink term $\left(Q_{c}\right.$ in Eq. (5)). The modelling of $E$. coli die-off required: (i) a literature search for a suitable formula to represent the process and (ii) FORTRAN programming of the chosen formula in a user-defined TELEMAC-3D subroutine.

A literature search of the available approaches for modelling die-off of bacteria (e.g. Auer and Niehaus, 1993; Beaudeau et al., 2001; Chapra, 1997; Darakas, 2002; Kashefipour et al., 2002, 2006) has highlighted an interesting process-based first-order kinetics formula developed by Mancini (1978) who integrated the findings of a number of studies on the decay of coliform bacteria in both fresh and marine waters and included the effects of temperature, salinity, and solar radiation (Crane and Moore, 1986).

Mancini's formula was used in the current study to produce a time- and space-dependent die-off rate $(k)$ of E. coli:

$\frac{\partial C}{\partial t}=-k C$

$k=\left[0.8+0.006(\% s w) * 1.07^{(T-20)}+\frac{I_{A}}{k_{e} H}\left[1-e^{-k_{e} H}\right]\right.$

$\% s w$ is the salinity expressed as percentage seawater (in the original form of equation by Mancini (1978)). In implementing the Mancini model, it was assumed that $100 \%$ sw corresponds to 35.5 PSU, one of the highest salinity value recorded in the study area.

$H$ is the mixed water depth $(\mathrm{m})$, but due to the absence of information about $H$, it has been treated as a parameter (i.e. a ratio of the total water depth which is calculated by the hydrodynamic equation). A possible range of values (0.0-1.0) for this ratio has been attempted and the best match between measured and simulated $E$. coli was achieved when the ratio was 1.0 (i.e. when the mixed depth is taken as the total water depth). This has produced values of decay rates that are quite comparable to those in the literature.

$I_{A}$ is the average daily surface solar radiation (langleys/h) recorded at the nearest weather station (Dublin Airport), and $k_{e}$ is the light extinction coefficient $\left(\mathrm{m}_{\wedge}^{-1}\right)$ computed using the formula:

$k_{e}=\frac{1.7}{\mathrm{SD}}$

where SD is the depth at which Secchi disc is no longer visible (m), obtained from measurements in the Liffey Estuary and Dublin Bay.

The Mancini decay rate formula (Eq. (7b)) has two components: the first is a three-dimensional term for which the decay rate varies with depth and is calculated from the values of temperature and salinity at each point and time in the model. The second term gives spatially-variable, but depth-averaged values of decay rate.

The decay rate of $E$. coli is generally expressed in terms of $T_{90}$ (the time taken for the $E$. coli concentration to be reduced by $90 \%)$. The relationship between $k$ and $T_{90}$ is:

$k=\frac{2.303}{T_{90}}$

\subsection{Turbulence modelling}

Turbulence models set the spatial (horizontal $x-y$ ) and vertical scale of velocities and tracers in the model domain. In this study, horizontal turbulence is modelled using the sub-grid scale Smagorinsky scheme (Smagorinksy, 1963 cited in Hervouet, 2007). This scheme allows for the formation of smaller vortices 
where turbulence can be inhibited by the mesh, rendering it a suitable choice for this study where the element size of the finite element mesh varies considerably over the domain.

For the resolution of the vertical diffusion coefficients (the eddy viscosity $v_{z}$ in Eqs. (2) and (3) and the eddy diffusivity $K_{z}$ in Eq. (5)), the mixing length turbulence closure approach was applied.

$v_{z}=\phi_{m} l^{2} \sqrt{\left(\frac{\partial u}{\partial z}\right)^{2}+\left(\frac{\partial v}{\partial z}\right)^{2}}$

$K_{z}=\phi_{T} l^{2} \sqrt{\left(\frac{\partial u}{\partial z}\right)^{2}+\left(\frac{\partial v}{\partial z}\right)^{2}}$

where $l$ is the mixing length, $\varphi_{m}$ and $\varphi_{T}$ are the damping functions of velocity and tracers respectively to account for the decrease of eddy viscosity and diffusivity with increasing stratification. These empirical functions can be used to fine-tune the vertical profiles of velocity and tracers to measurements, and can take several forms; the most commonly used form is the Munk and Anderson (1948) type of formula:

$\phi_{m}=\frac{v_{z}}{v_{z o}}=m\left(1+\beta R_{i}\right)^{\alpha}$

$\phi_{T}=\frac{K_{z}}{K_{z o}}=n\left(1+b R_{i}\right)^{a}$

$R_{i}$ is the Richardson number defined by:

$R_{i}=-g \frac{\frac{1}{\rho} \frac{\partial \rho}{\partial z}}{\left(\frac{\partial u}{\partial z}\right)^{2}+\left(\frac{\partial v}{\partial z}\right)^{2}}$

$v_{z}$ and $v_{z o}$ are water vertical viscosity in stratified and neutral conditions respectively, and $K_{z}$ and $K_{z o}$ are the tracers vertical viscosity in stratified and neutral conditions respectively. $m, n, \beta, \alpha, b$, and $a$ are empirical coefficients.

In this study, we compare two mixing length formula; the Classical Prandtl (1925) cited in Hervouet (2007) and the Nezu and Nakagawa (1993) models (Table 1):

In order to achieve a suitable match to the vertical profiles of temperature and salinity, a collection of decay functions, obtained from the literature and coded in a FORTRAN subroutine to be applied to the current case study (Table 2). These were then compared to measured profiles of temperature and salinity (Section $5.2)$.

\section{Methods}

\subsection{Modelling approach}

A finite element mesh of the model domain (Fig. 1) was constructed based on Delauney triangulation EDF, 1998) using bathymetric data obtained from a number of surveys and Admiralty charts. The domain extends for a distance of $29.5 \mathrm{~km}$ in the eastwest direction and $38.5 \mathrm{~km}$ in the north-south direction with a mesh size ranging from $750 \mathrm{~m}$ at the open sea boundary to $12.5 \mathrm{~m}$ in the vicinity of the ESB discharge outfall. The vertical grid consisted of 6 layers of varying thickness.

Using the mesh, initial and boundary conditions (described in Section 4.2), the TELEMAC-3D model simulated the water flow fields and distributions of temperature, salinity and E. coli in the Liffey Estuary and Dublin Bay for a baseline scenario from the period prior to the cessation of thermal discharges for which measured data is available. A mean neap tide (of a range of $1.9 \mathrm{~m}$ ) was selected for the simulations because; (i) previous studies showed that neap tide conditions generally tend to be critical for
Table 1

TELEMAC-3D mixing length models.

\begin{tabular}{ll}
\hline Mixing length model & Formula of mixing length $(l)$ \\
\hline Classical Prandtl (1925) & $l=k z$ if $z \leqslant 0.2 h$ \\
& $l=0.2 \mathrm{kh} \mathrm{if} z \geqslant 0.2 h$ \\
Nezu-Nakagawa (1993) & $l=k z \sqrt{1-\frac{z}{h}}$
\end{tabular}

$k$ is the von Karman constant $(0.41), z$ is the distance to the bottom and $h$ is the water depth.

water quality in Dublin Bay, and (ii) the availability of measured current velocity, temperature, salinity and E. coli taken on days in which mean neap tide conditions prevailed (Bedri, 2007; Crisp, 1976; Irish Hydrodata, 1994). Model adjustment to measurements was achieved through calibration of bottom friction, vertical turbulence, and E. coli decay rate (Section 4.3).

This calibrated TELEMAC-3D model was then used to simulate and compare two discharge scenarios of the period following the shut-down of the ESB plant.

\subsection{Initial and boundary conditions}

The simulations of the Dublin Bay model start from quiescent conditions (i.e. zero water velocities and a constant mean sea water level). Initial/background temperature and salinity in the domain were obtained from depth measurements at a number of locations in the Liffey Estuary and inner Bay on days where mean neap tide conditions prevailed. The background E. coli concentration was set to zero.

The boundary conditions of the model were:

(i) Open Sea boundaries: These are time-varying mean neap tidal elevations at the north and south boundaries. Only the tidal constituents with amplitudes greater than $10 \mathrm{~mm}$ (identified from measurements at gauges in Dublin Bay as $M_{2}, S_{2}$, $N_{2}, K_{2}, K_{1}$, and $O_{1}$ ) were selected to drive the hydrodynamic model (Hussey, 1996; Mansfield, 1992). Background values of temperature, salinity and E. coli were assigned.

(ii) Eastern Seaward boundary: Flow observations and currentmeter measurements at the outer bay (see Bedri et al., 2011) demonstrated that the flow is predominantly NorthSouth in this region of the Bay. Therefore a mirror-type boundary was used in which flow is permitted parallel to the boundary but not across it. Also here, background values of temperature, salinity and E. coli were assigned.

(iii) ESB outfall: This is where the combined discharges of the Poolbeg power generation plant and Ringsend Sewage Plant enter the Estuary. Temperature at this inflow boundary was considerably higher, and salinity was lower than those of the ambient waters. Discharged E. coli concentrations, obtained from measurements by local authorities, were subjected to a dilution factor of 8 to account for the effect of mixing with the cooling water from the ESB Thermal Plant at Poolbeg.

(iv) River Liffey: The regulated river flow of $12.42 \mathrm{~m}^{3} / \mathrm{s}$ may increase during high flow period when streams and combined sewer overflows contribute to the inflow into the bay. However, in the case under study, dry weather prevailed over the week preceding the sampling/simulated days; thus, it was reasonable to ignore the riverine input of $E$. coli which, in such circumstances, contributes less than $1 \%$ of the total E. coli load to the Bay (Wilson, 2005). Background temperature and salinity values of the Liffey River were established from previous measurements (Crisp, 1976; O'Higgins and Wilson, 2005). 
Table 2

Vertical turbulence model schemes tested.

\begin{tabular}{|c|c|c|c|c|c|c|c|c|}
\hline \multirow[t]{2}{*}{ Test case } & \multirow[t]{2}{*}{ Mixing length model } & \multirow[t]{2}{*}{ Damping function } & \multicolumn{3}{|c|}{$\begin{array}{l}\text { Velocity damping } \\
\text { coefficients }\end{array}$} & \multicolumn{3}{|c|}{$\begin{array}{l}\text { Tracer damping } \\
\text { coefficients }\end{array}$} \\
\hline & & & $\beta$ & $\alpha$ & $m$ & $B$ & $a$ & $n$ \\
\hline TURB1 & Classical Prandtl (1925) & Munk and Anderson (1948) & 10 & -0.5 & 1 & 3.33 & -1.5 & 1 \\
\hline TURB2 & Classical Prandtl (1925) & Viollet (1977) cited in Viollet (1988) & 14 & -1.5 & 1 & 14 & -0.75 & 1 \\
\hline TURB 3 & Classical Prandtl (1925) & Lehfeldt and Bloss (1988) & 3 & -1 & 1 & 3 & -3 & 1 \\
\hline TURB 4 & Classical Prandtl (1925) & Bowden and Hamilton (1975) & 7 & -0.25 & 1 & 1 & -1.75 & 1 \\
\hline TURB 5 & Nezu and Nakagawa (1993) & Park and Kuo (1994) with calibrated parameters $(m=n)$ and $(B=\beta)$ & 1.5 & -0.5 & 0.035 & 1.5 & -1.5 & 0.035 \\
\hline
\end{tabular}

\subsection{Model parameters: sensitivity and calibration}

The most sensitive parameters that significantly influence the outputs of the model were identified as bottom friction, vertical turbulence scheme, and $\underset{\Lambda}{\mathrm{E}}$. coli decay rate.

\subsubsection{Bottom friction}

The bottom friction (Chezy coefficient) of the TELEMAC-3D model was subsequently varied to achieve a match with the measured velocities. First, a value for the bottom friction was estimated and the model was run until its hydrodynamics variables demonstrated a quasi-steady state. The model outputs (three-dimensional water velocity) were then compared against velocity measurements taken on days which had a tidal range of approximately $1.9 \mathrm{~m}$ at eight locations (locations $\mathrm{H} 1-\mathrm{H} 8$ in Fig. 2).
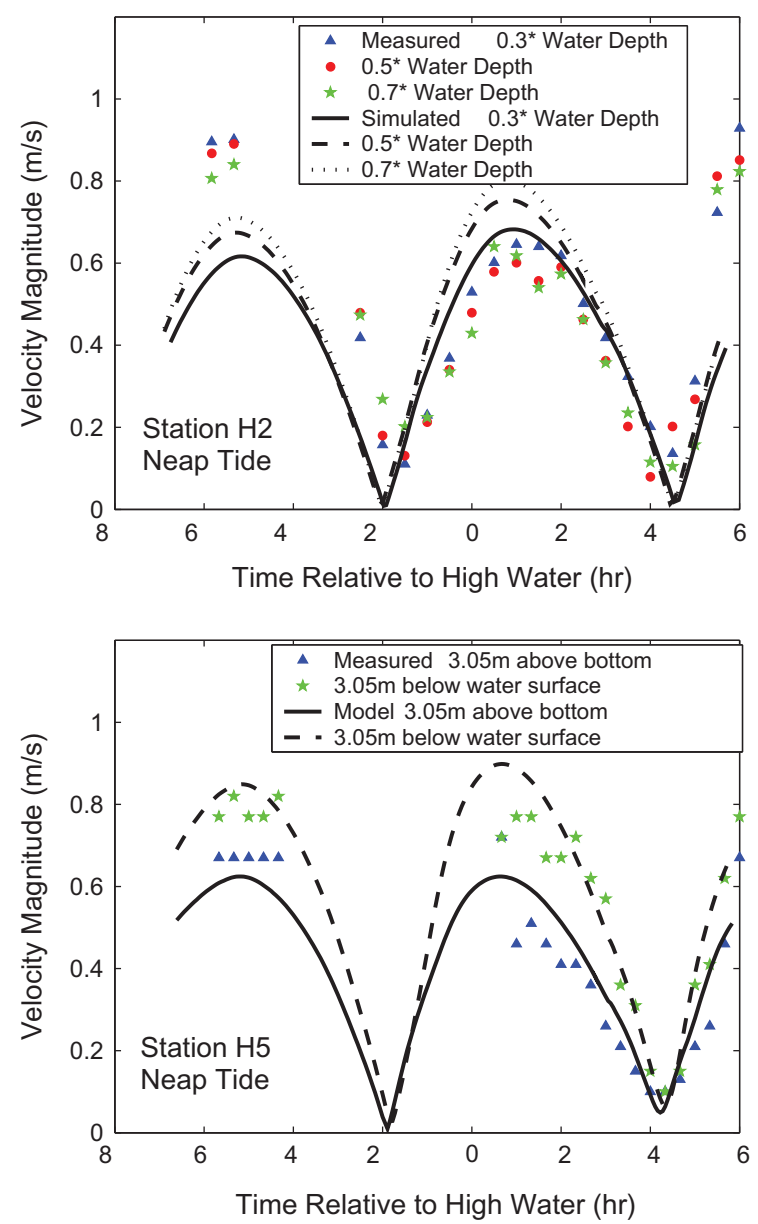

\subsubsection{Turbulence modelling}

In these simulations (Table 2), the vertical turbulence model and damping functions were subsequently varied to improve the fit between the measured and simulated vertical profiles of temperature and salinity at S12 and S10 (Fig. 2). All selected damping functions have the structure of the Munk and Anderson formula (Eqs. (9a) and (9b)). In all test cases (Table 2), except for the Park and Kuo function (TURB5), the value of damping functions become 1 when there is no stratification. However, the Park and Kuo function was used in the study because it offers some flexibility by allowing the calibration of two parameters $m$ (or $n$ ) and $B($ or $\beta$ ) to fit measured profiles of velocity, temperature or salinity.

\subsubsection{E. coli decay}

Initially, a number of simulations were carried out using a range of constant values of decay rate to test the $E$. coli model sensitivity.
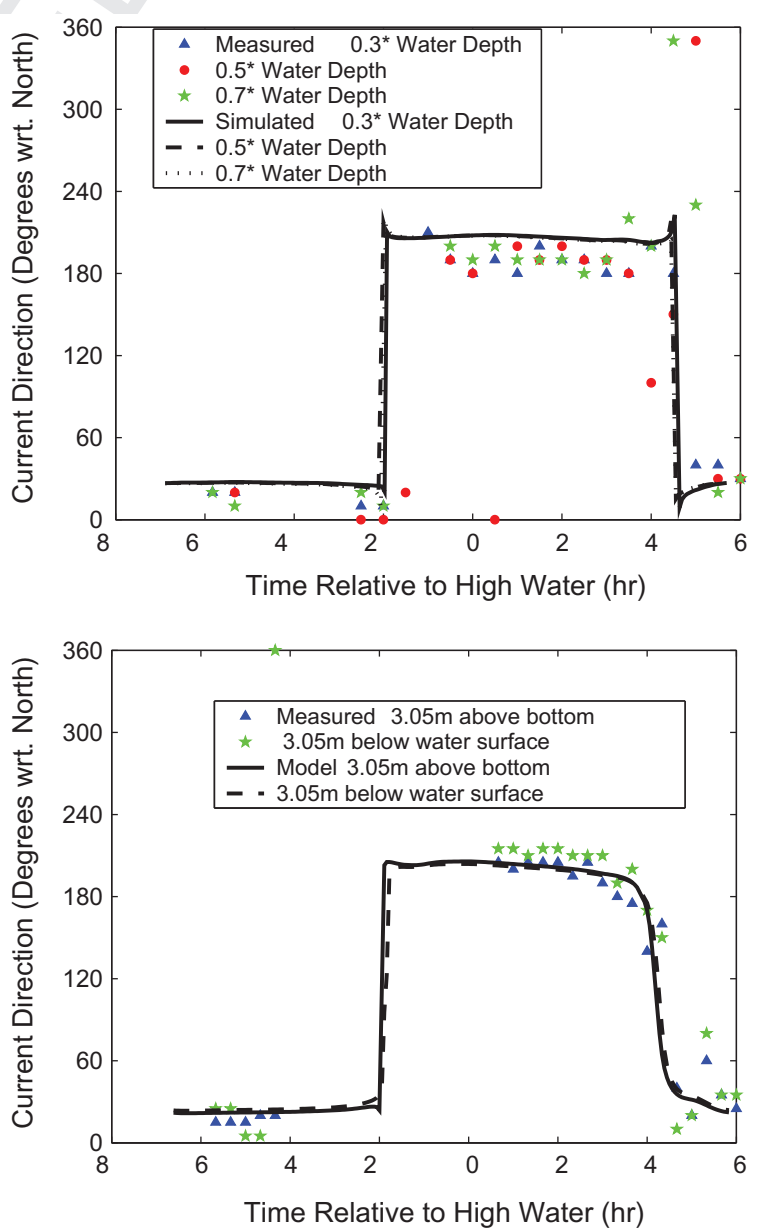

Fig. 3. Simulated and measured current speed and direction at points $\mathrm{H} 2$ and $\mathrm{H} 5$. 
For a chosen value of decay rate $\left(T_{90}\right)$, the model was run until a quasi-steady state was reached (after 8 tidal cycles). The model outputs of the last tidal cycle were then used for comparison with measured $E$. coli concentrations taken at the water surface at location M1 shown in Fig. 2. Thereafter, simulations of $E$. coli distribution were performed using the variable decay rate in Eq. (7b) which is based on time- and space-varying simulated variables (temperature, salinity, and water depth). These were compared with measurements at locations M1 and M2.

\subsection{Model șcenarios}

Finally, the model calibrated to the base-line scenario (Scenario 1) was used to simulate two hydrodynamic and water quality scenarios to predict the bathing water quality in the inner Bay for the period following the ESB plant shut-down. The scenarios are:

(i) Scenario 2 - Dilution scenario: Cessation of ESB thermal discharges but continued extraction of estuary water to dilute wastewater discharges from Ringsend STW.

(ii) Scenario 3 - Do nothing scenario: where the sewage effluent is discharged directly into the estuary without prior dilution. This is the current scenario practiced at Ringsend STW.

\section{Results: model calibration}

\subsection{Tidal hydrodynamics}

A Chezy coefficient value of 50 produced the best match between simulated velocities and measurements. The detailed results
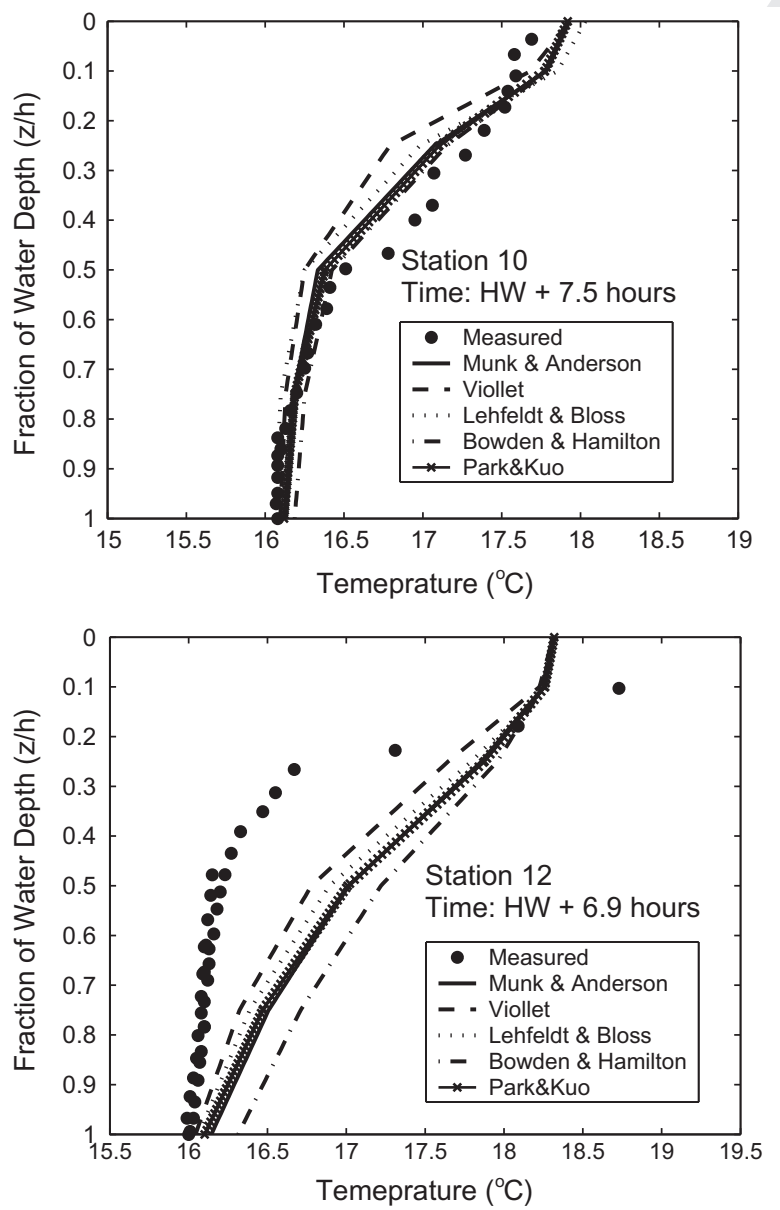

for two representative points (Points $\mathrm{H} 2$ and $\mathrm{H} 5$ ) are discussed below.

The model replicated the measured velocity pattern at both stations reasonably well (Fig. 3). The simulated velocity at Station H5 generally matched the measurements better than Station $\mathrm{H} 2$. At Station 5, both the simulated velocities at $3.05 \mathrm{~m}$ below the water surface and $3.05 \mathrm{~m}$ above the bottom were comparable to measurements, particularly after the time of high water. At Station $\mathrm{H} 2$, the simulated velocities at 0.3 of the water depth gave a better fit to measurements compared to the model outputs at 0.5 and 0.7 of the water depth.

Station $\mathrm{H} 5$ replicated well the residual currents of the neap tide (these are random velocities of small values that occur close to the time of turn of the tide, caused by the nonlinear interactions of tidal currents and irregular bathymetry). These were underestimated by the model at Station $\mathrm{H} 2$ by approximately $0.1 \mathrm{~m} \mathrm{~s}^{-1}$.

The observed flow direction was adequately simulated by the model at both stations but better at Station H5.

\subsection{Vertical turbulence schemes}

Using the adjusted value for bottom friction coefficient, simulations of TELEMAC-3D (denoted by continuous lines in Fig. 4) were performed for each of the vertical turbulence schemes in Table 2.

Measurements of depth profiles of temperature and salinity (shown as points in Fig. 4) at locations S10 and S12 were taken close to the time of low water where stratification is believed to be greatest. These were taken at $\mathrm{HW}+6.9$ and $\mathrm{HW}+6.5 \mathrm{~h}$ respectively and were repeated $1 \mathrm{~h}$ later (HW is the time of high water). The measured temperature at the water surface was higher (and
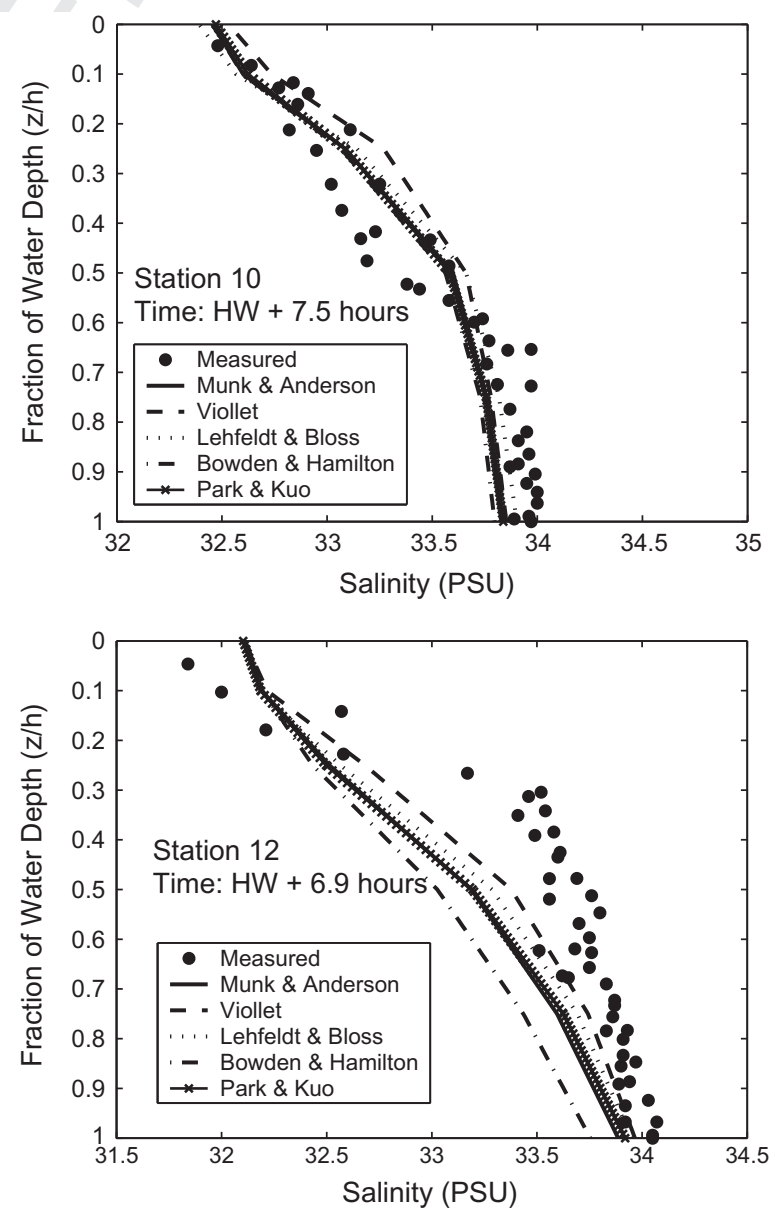

Fig. 4. Measured and simulated temperature and salinity vertical profiles at S12 and S10 using different damping schemes. 
Table 3

Varying vertical turbulence models: Root Mean Squares of Errors (RMSEs) between measured and computed temperature and salinity at S12 and S10.

\begin{tabular}{|c|c|c|c|c|}
\hline \multirow[t]{3}{*}{ Simulation } & \multicolumn{4}{|c|}{ Station (sampling time) } \\
\hline & \multicolumn{2}{|l|}{$\mathrm{S} 12$} & \multicolumn{2}{|l|}{ S10 } \\
\hline & $\mathrm{HW}+6.9 \mathrm{~h}$ & $\mathrm{HW}+7.9 \mathrm{~h}$ & $\mathrm{HW}+6.5 \mathrm{~h}$ & $\mathrm{HW}+7.5 \mathrm{~h}$ \\
\hline (1) Munk and Anderson temperature salinity & $\begin{array}{l}1.377 \\
0.843\end{array}$ & $\begin{array}{l}1.455 \\
0.738\end{array}$ & $\begin{array}{l}0.290 \\
0.512\end{array}$ & $\begin{array}{l}0.452 \\
0.326\end{array}$ \\
\hline (2) Viollet temperature salinity & $\begin{array}{l}1.016 \\
0.573\end{array}$ & $\begin{array}{l}1.339 \\
0.673\end{array}$ & $\begin{array}{l}0.441 \\
0.695\end{array}$ & $\begin{array}{l}0.427 \\
0.382\end{array}$ \\
\hline (3) Lehfledt and bloss temperature salinity & $\begin{array}{l}1.194 \\
0.702\end{array}$ & $\begin{array}{l}1.318 \\
0.655\end{array}$ & $\begin{array}{l}0.391 \\
0.618\end{array}$ & $\begin{array}{l}0.384 \\
0.330\end{array}$ \\
\hline (4) Bowden temperature salinity & $\begin{array}{l}1.693 \\
1.087\end{array}$ & $\begin{array}{l}1.693 \\
0.921\end{array}$ & $\begin{array}{l}0.275 \\
0.418\end{array}$ & $\begin{array}{l}0.499 \\
0.337\end{array}$ \\
\hline (5) Park and Kuo temperature salinity & $\begin{array}{l}1.358 \\
0.827\end{array}$ & $\begin{array}{l}1.470 \\
0.753\end{array}$ & $\begin{array}{l}0.254 \\
0.479\end{array}$ & $\begin{array}{l}0.450 \\
0.317\end{array}$ \\
\hline
\end{tabular}

the salinity lower) at location S12 than S10 due to being nearer the discharge outfall.

TELEMAC-3D simulations in Fig. 4 show that the largest temperature and salinity gradients occur with the Viollet scheme (at S10) and the Viollet and the Bowden \& Hamilton (at S12). The Munk \& Anderson and Park \& Kuo schemes gave identical vertical profiles at both stations.

The root mean squares of errors (RMSEs) were computed (Table 3 ) for each of the simulations to assess the goodness of fit of simulated temperature and salinity profiles to measurements at S12 and S10. Both temperature and salinity profiles at S10 fitted the measurements better than S12. This is reflected in the RMSE values (Table 3) which are significantly higher at S12 than at S10. This is perhaps due to the close proximity of S12 to the discharge weir, therefore being in the zone of radial flow of effluents. This mixed flow field may have caused a less-defined response compared to S10 which is under the influence of unidirectional tidal flow into the estuary.

The lowest values for RMSE at S12 were achieved by the Viollet and Lehfelt and Bloss schemes while at S10, the Park and Kuo scheme gave the lowest RMSE (except for temperature at $\mathrm{HW}+7.5 \mathrm{~h}$ ). An overall comparison of the RMSE values at S12 and S10 indicates that the Park \& Kuo scheme generally produced the best match to measurements and hence is used in the simulations discussed in Sections 4.3.3 and 4.4.

\subsection{E. coli model}

Simulated E. coli at M1 and M2 demonstrated a distinctive pattern over the tidal cycle (Fig. 5) where concentrations reached their peak values at around the time of mid flood (HW-2 to $\mathrm{HW}-4 \mathrm{~h}$ ) then gradually decreased to a minimum around the time of low water (HW+6 and HW-6 h). In contrast, measured E. coli concentrations exhibited considerable random variation over the tidal cycle although the values remained within one order of magnitude.

Using a constant decay rate of E. coli (Fig. 5a), simulations showed that the decay rates $T_{90}=3,6$ and $12 \mathrm{~h}$ have produced a suitable envelope to match the order of magnitude of measured E. coli with a $T_{90}$ value of $6 \mathrm{~h}$ being slightly better. The simulation using a variable decay rate, improved somewhat on the constant decay rate results At $\mathrm{M} 2$, the simulated E. coli concentrations (using the variable decay rate) showed a reasonable fit to some measurements on the flooding stage (HW-6 to HW-3 h). However, the model has underestimated observed E. coli concentrations around the time of low water $(\mathrm{HW}+4$ to $\mathrm{HW}+6)$. The same has been observed at location M1 (Fig. 5a). The comparison be-
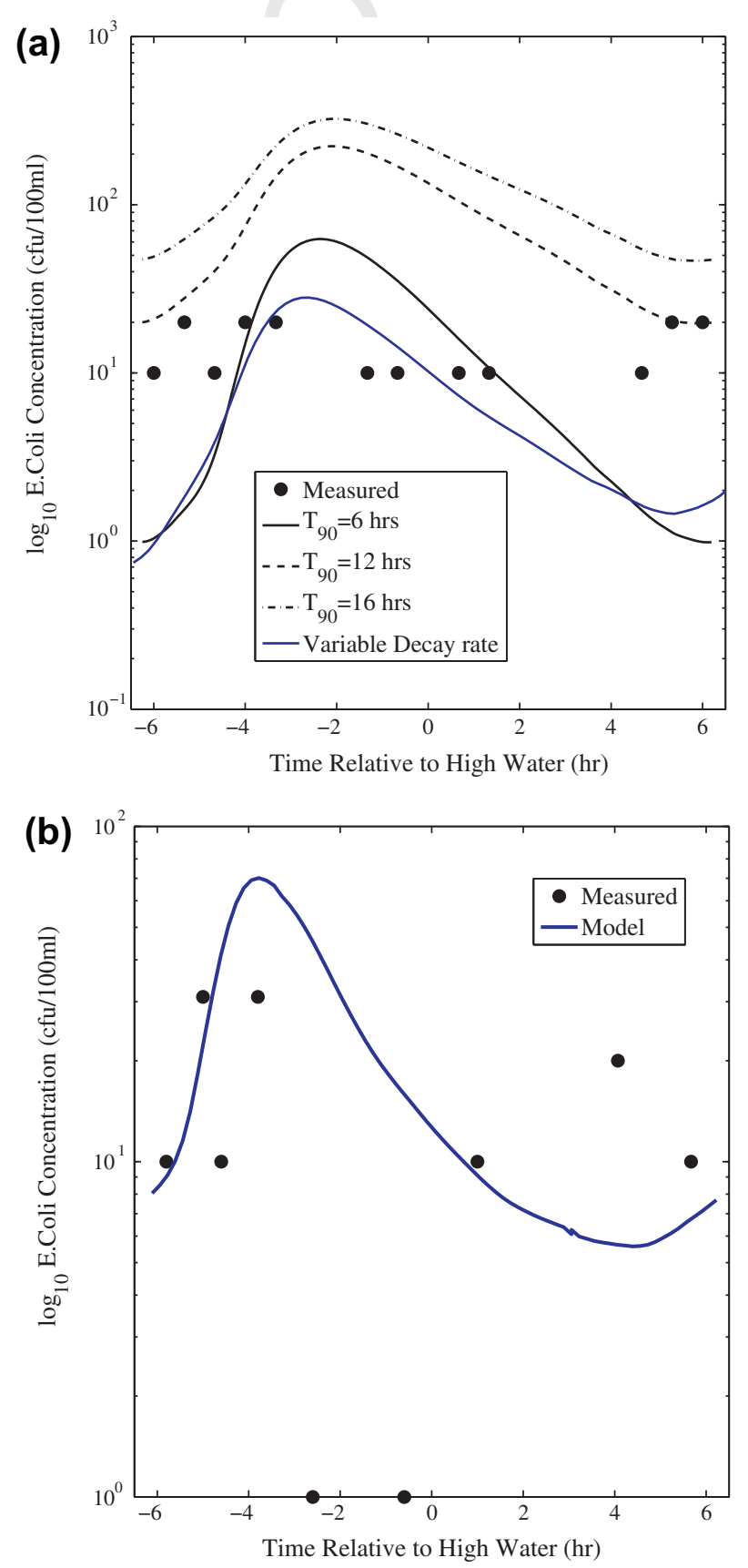

Fig. 5. Comparison of simulated and measured E. coli concentrations at Points M1 and M2 (in Fig. 2). 

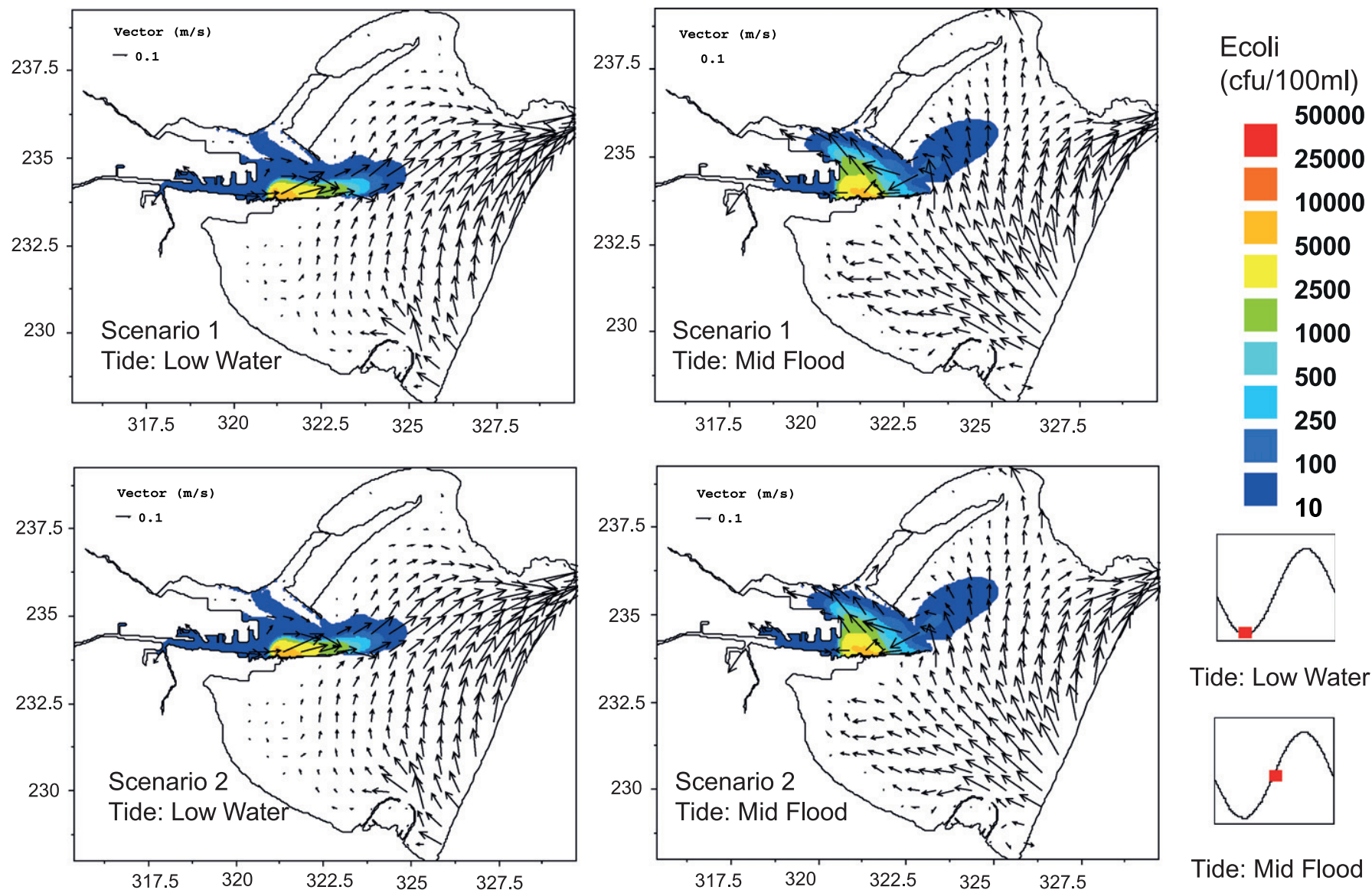

Tide: Low Water

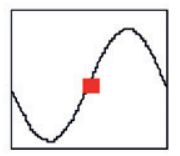

Tide: Mid Flood
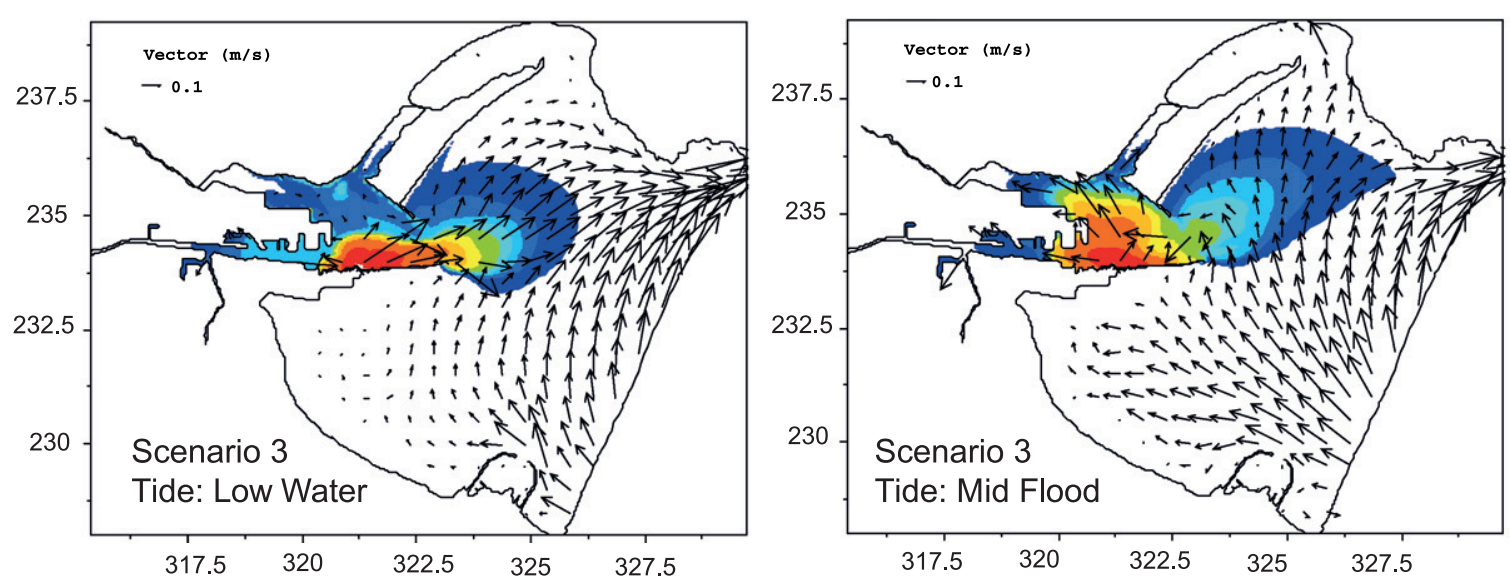

Water Elevation at Dublin Port

tween measured and simulated E. coli concentrations at M1 and M2 show that the variable decay rate model captures the order of magnitude of measured E. coli, and fits some of the measurements. However, it was not possible to accurately predict the measured E. coli concentrations because of their highly random variation over a tidal cycle. This random variation in measured E. coli concentrations can be due to; (i) the complex physical and biological processes that govern the growth and die-off of E. coli even within the confinement of a bottled sample, (ii) the difficulty in achieving the ideal environmental conditions for sample storage and transport, and (iii) the uncertainty in the measurements, particularly in the enumeration of $E$. coli colonies even under controlled laboratory conditions.
6. Results: comparison of water quality pre- and post-ESB shutdown ${ }^{\wedge}$

Fig. 6 shows the simulated distribution of E. coli in the Liffey Estuary and Inner Bay at two stages in the tidâl cycle; low water slack and mid flood. The model has satisfactorily replicated the observed flow patterns in the Estuary and Inner Bay; the ebbing tide pushes the discharge plume eastwards out of the Estuary and into the Bay, draining water out of South Bull Lagoon (Fig. 2). Once in the bay, the plume flows eastwards and is then deflected northwards, first towards Dollymount Strand and then further eastwards towards Howth Head. During the flood tide, the incoming, less polluted, water pushes the plume back into the har- 

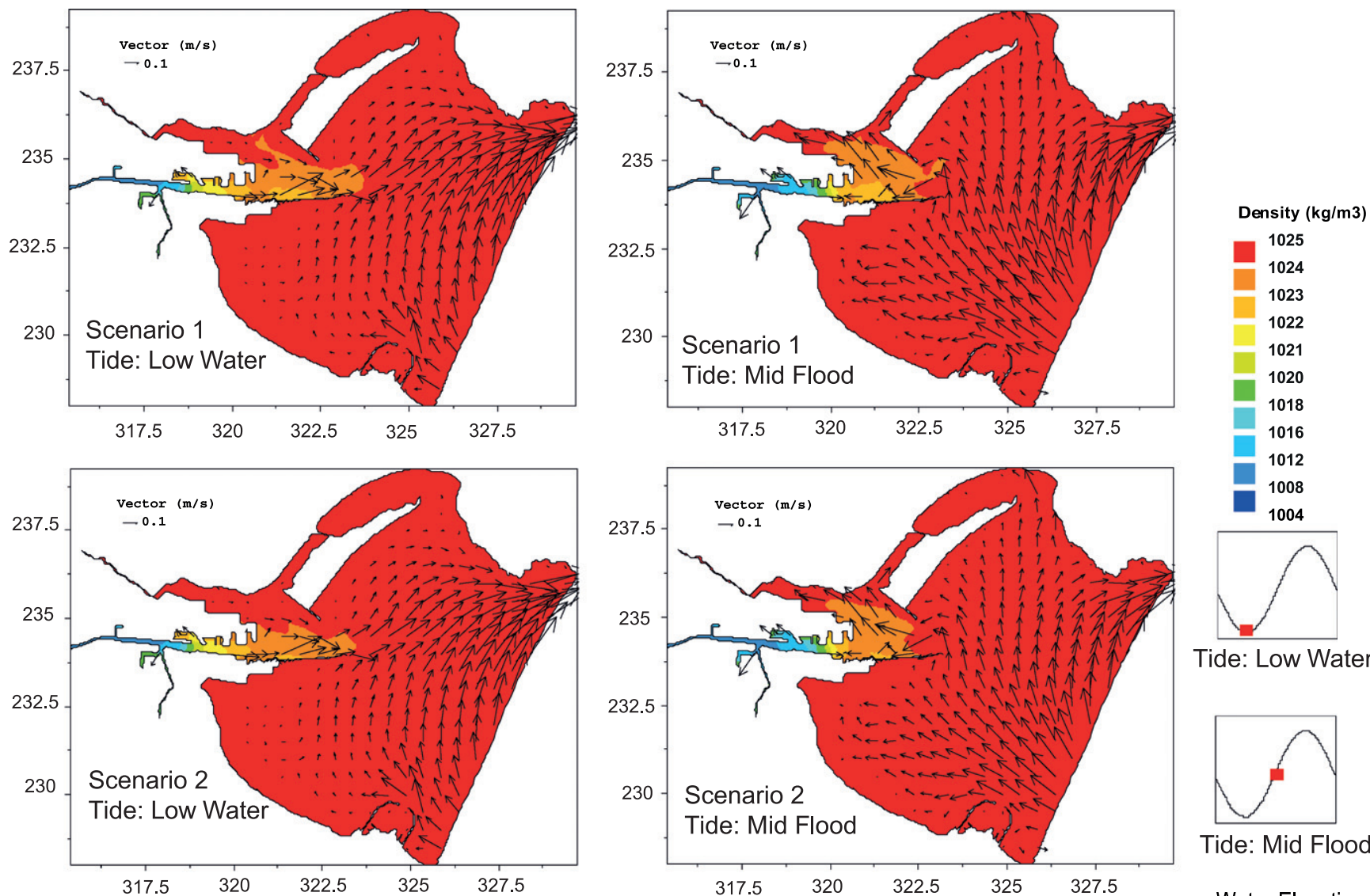

Tide: Low Water

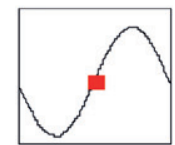

Tide: Mid Flood

Water Elevation
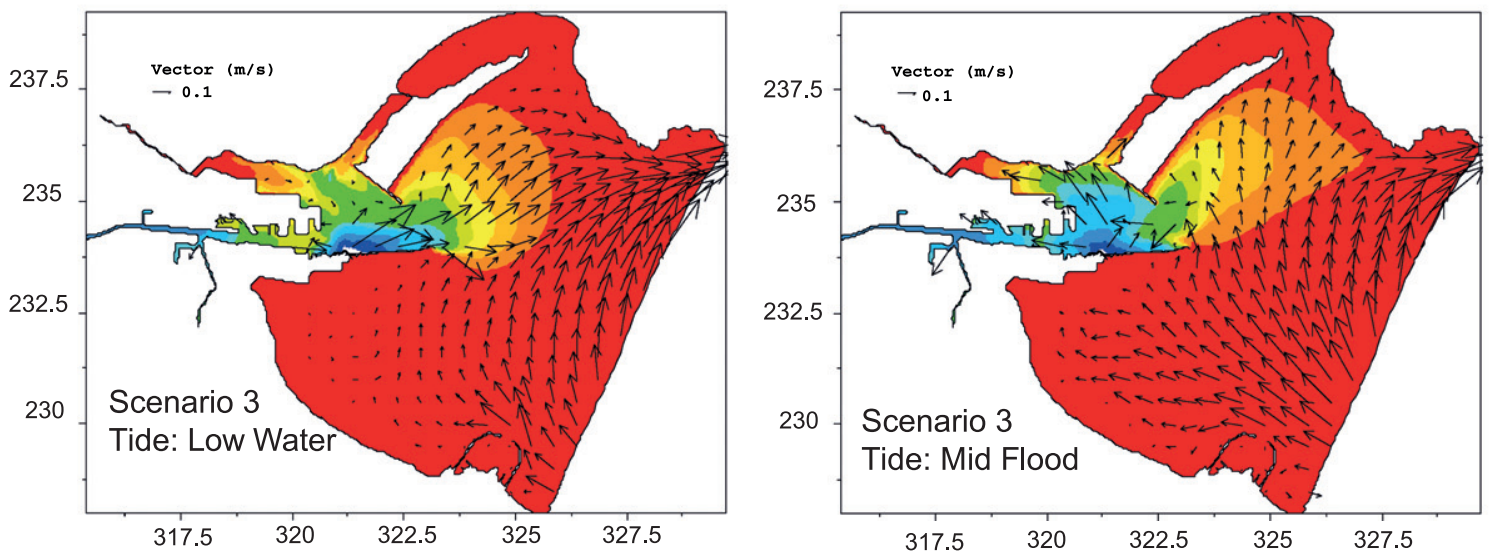

at Dublin Port

Fig. 7. Density at the water surface at low water and mid flood stages of the tidal cycle.

bour and up the Liffey estuary, while in the inner bay and in the vicinity of the harbour mouth, the flood tide sweeps the discharge plume northwards towards Dollymount Strand.

Fig. 6 shows no difference in the distribution of $E$. coli between Scenarios 1 and 2 in the Estuary and Inner Bay. This is due to the minor effect of heat elimination from the cooling water in Scenario 2 on the water density (Fig. 7) and therefore on the flow fields and transported waste.

Scenario 3, which is the discharge strategy currently practiced at Ringsend STW, shows considerably higher concentrations of $E$. coli in the Estuary and Inner Bay in comparison to Scenarios 1 and 2 (Fig. 6) due to the absence of prior dilution. The effect of the abstracted dilution water from the estuary was two-fold; (i) it provided dilution to the effluent thus reducing the E. coli concentrations discharged into the estuary, and (ii) it reducêd the salinity difference between the effluent and ambient water and hence stratification which has a direct effect on the flow field. Therefore the absence of dilution means a higher density difference in Scenario 3 compared to Scenarios 1 and 2 (Fig. 7) which is subsequently reflected on the flow field and a greater rate of delivery of pollutants to the Inner Bay.

In terms of the water quality at the beaches, the mid flood stage (Scenario 3) gives higher counts of E. coli at Dollymount Strand than does the low water stage. This is because at the high water levels during an incoming tide, there is a direct hydraulic connection with the estuary over the North Wall (Fig. 2) which is submerged at flood stage. Also at the time of mid flood, E. coli concentrations in the vicinity of Dollymount Strand were 250 $500 \mathrm{cfu} / 100 \mathrm{ml}$ (Scenario 3) which are the limits for excellent and good quality standards of the EU Bathing Water Directive 
(2006/7/EC). Fig. 6 shows that the water quality at Sandymount and Merrion Strand is less impaired than Dollymount Strand because of the South wall which extends a long distance eastwards into the bay, separating the waters of the beaches on the south side of the bay from the flow exiting the estuary. Hence the south wall prevents the $E$. coli plume from flowing directly southwards to the beaches of Sandymount and Merrion Strand except when the wind is from the north east direction.

\section{Conclusion}

This paper investigates the effect of cessation of thermal discharges from a power plant on the stratified flow and its implications to the bathing water quality of Dublin Bay. Before closing down, a practice was in place where sewage effluent from a nearby treatment plant was mixed with thermal discharges before being released into the Liffey Estuary resulting in a warm, less-saline buoyant sewage plume that has reduced mixing properties. The model was first calibrated based on measured hydrodynamic and water quality data from the period before the cessation of thermal discharges (Scenario 1). The calibrated model was then used to assess the bathing water quality under two scenarios following the thermal plant shut down (i) Bilution scenario: where a continued abstraction of estuary water is used to dilute sewage effluent before being released into the estuary (Scenario 2), and (ii) Đo nothing scenario where the sewage effluent is discharged directly into the estuary (Scenario 3).

Results showed that there was an insignificant difference in the distribution of $E$. coli between Scenarios 1 and 2 . However, Scenario 3 resulted in considerably higher $E$. coli concentrations in the Estuary and inner Bay due to the increased stratification caused by the absence of prior dilution.

Therefore, continued abstraction of dilution water post-ESB shut-down may be better for bathing water quality than direct discharges of effluents into the Estuary.

\section{Acknowledgements}

This research has been jointly funded by an INTERREG IIIA (Ireland and Wales) project and the Marine Institute, Ireland. The TELEMAC modelling package has been developed by Electricité de France, technical support and maintenance has been provided by Hydraulic Research (HR) Wallingford, UK. Thanks are extended to Sébastien Bourban of HR Wallingford, for his advice and useful comments.

\section{References}

Abbaspour, M., Javid, A.H., Moghimi, P., Kayhan, K., 2005. Modeling of thermal pollution in coastal area and its economical and environmental assessment. International Journal of Environmental Science and Technology 2, 13-26.

Abdul-Wahab, S.A., Jupp, B.P., 2009. Levels of heavy metals in subtidal sediments in the vicinity of thermal power/desalination plants: a case study. Desalination $244,261-282$.

Auer, M.T., Niehaus, S.L., 1993. Modeling fecal coliform bacteria-I. Field and laboratory determination of loss kinetics. Water Research 27, 693-701.

Baba, A., Kaya, A., Birsoy, Y.K., 2003. The effect of Yatagan thermal power plant (Mugla, Turkey) on the quality of surface and ground waters. Water, Air, and Soil pollution 149, 93-111.

Beaudeau, P., Tousset, N., Bruchon, F., Lefevre, A., Taylor, H.D., 2001. In situ measurement and statistical modelling of Escherichia coli decay in small rivers. Water Research 35, 3168-3178.

Bedri, Z., 2007. Three-dimensional Hydrodynamic and Water Quality Modelling of Dublin Bay. Ph.D. Thesis, University College Dublin, National University of Ireland.

Bedri, Z., Bruen, M., Dowley, A., Masterson, B., 2011. A Three-Dimensional HydroEnvironmental Model of Dublin Bay. Environmental Modeling and Assessment $16,369-384$

Bouvy, M., Briand, E., Boup, M.M., Got, P., Leboulanger, C., Bettarel, Y., Arfi, R., 2008. Effects of sewage discharges on microbial components in tropical coastal waters (Senegal, West Africa). Marine and Freshwater Research 59, 614-626.
Bowden, K.F., Hamilton, P., 1975. Some experiments with a numerical model of circulation and mixing in a tidal estuary. Estuarine and Coastal Marine Science 3, 281-301

Casulli, V., Walters, R.A., 2000. An unstructured grid, three-dimensional model based on the shallow water equations. International Journal for Numerical Methods in Fluids 32, 331-348.

Cea, L., Bermúdez, M., Puertas, J., 2011. Uncertainty and sensitivity analysis of a depth-averaged water quality model for evaluation of Escherichia Coli concentration in shallow estuaries. Environmental Modelling and Software 26, 1526-1539.

Chapra, S.C., 1997. Surface Water-quality Modeling. MGraw-Hill, Boston.

Choi, K.-H., Kim, Y.-O., Lee, J.-B., Wang, S.-Y., Lee, M.-W., Lee, P.-G., Ahn, D.-S., Hong, J.-S., Soh, H.-Y., 2012. Thermal impacts of a coal power plant on the plankton in an open coastal water environment. Journal of Marine Science and Technology 20, 187-194.

Chuang, Y.-L., Yang, H.-H., Lin, H.-J., 2009. Effects of a thermal discharge from a nuclear power plant on phytoplankton and periphyton in subtropical coastal waters. Journal of Sea Research 61, 197-205.

Crane, S.R., Moore, J.A., 1986. Modeling enteric bacterial die-off: a review. Water, Air, and Soil pollution 27, 411-439.

Crisp, J., 1976. Survey of Environmental Conditions in the Liffey Estuary and Dublin Bay, Summary Report to the ESB and Dublin Port and Docks Board. University College of North Wales, Bangor.

Darakas, E., 2002. E. coli kinetics - effect of temperature on the maintenance and respectively the decay phase. Environmental Monitoring and Assessment 78, 101-110.

Daviero, G.J., Roberts, P.J.W., 2006. Marine wastewater discharges from multiport diffusers. III: Stratified stationary water. Journal of Hydraulic Engineering 132, 404-410.

Dhage, S.S., Chandorkar, A.A., Kumar, R., Srivastava, A., Gupta, I., 2006. Marine Water Quality Assessment at Mumbai West Coast, Marine Pollution and Ecotoxicology, second ed.. Elsevier Ltd., pp. 149-158.

Donker, R.L., Jirka, G.H., 2007. CORMIX user manual: A Hydrodynamic Mixing Zone Model and Decision Support System for Pollutant Discharges into Surface Waters, EPA-823-K-07-001. USEPA, Washington, DC.

Dublin City Council (DCC), 2002. The Dublin Bay Project, Dublin Bay Water Quality Monitoring Programme, Technical Report 2. Central Laboratory, Dublin City Council, Ireland.

Dublin City Council (DCC), 2003. The Dublin Bay Project, Dublin Bay Water Quality Monitoring Programme, Technical Report 3. Central Laboratory, Dublin City Council, Ireland.

Dyer, K.R., 1973. Estuaries: A Physical Introduction. Wiley, Chichester.

EC, 2006. Council Directive 2006/7/EC of 15 February 2006 Concerning the Management of Bathing Water Quality and Repelling Directive 76/160/EEC. Official Journal L064, 04/03/2006.

EEC, 1992. Council Directive 92/43/EEC of 21 May 1992 on the Conservation of Natural Habitats and of Wild Fauna and Flora. Official Journal L206, 22/7/1992.

Electricité de France (EDF), 1997. TELEMAC modelling system. TELEMAC-3D. Version 2.2-Système de modélisation TELEMAC-3D Note Théorique, HE-42/ 97/049/B.

Electricité de France (EDF), 1998. TELEMAC Modelling system. Matisse User's Guide Version 1.0. Report EDF HE-42/98/004/A.

Ellis, K.V., 1989. Surface Water Pollution and its Control. Macmillan Press Ltd., Basingstoke and London.

Environmental Research Unit (ERU), 1992. Dublin Bay Water Quality Management Plan: Recreation, Amenity, and Wildlife Conservation Study. Technical Report 1, Environmental Research Unit.

Falconer, R.A., 1986. Water quality simulation study of a natural harbor. Journal of Waterway, Port, Coastal and Ocean Engineering - ASCE 112, 15-34.

Fernandez Torres, M.J., Ruiz Bevia, F., 2012. Chlorine use reduction in nuclear or conventional power plants: a combined cooling-and-stripping tower for coastal power plants. Journal of Cleaner Production 26, 1-8.

Frick, W.E., Roberts, P.J.W., Davis, L.R., Keyes, J., Baumgartner, D.J., George, K.P., 2003. Dilution Models for Effluent Discharges, fourth ed. U.S. Environmental Protection Agency, Washington, DC.

Gong, X., Yao, H., Zhang, D., Qiao, Y., Li, L., Xu, M., 2010. Leaching characteristics of heavy metals in fly ash from a Chinese coal-fired power plant. Asia-Pacific Journal of Chemical Engineering 5, 330-336.

Hartnett, M., Wilson, J.G., Nash, S., 2011. Irish estuaries: water quality status and monitoring implications under the water framework directive. Marine Policy $35,810-818$.

Havens, H., Luther, M.E., Meyers, S.D., Heil, C.A., 2010. Lagrangian particle tracking of a toxic dinoflagellate bloom within the Tampa Bay estuary. Marine Pollution Bulletin 60, 2233-2241.

Hervouet, J., 2007. Hydrodynamics of Free Surface Flows: Modelling with the Finite Element Method. Wiley, Chichester.

Hussey, M., 1996. Numerical Modelling of Cohesive Sediment Transport. Ph.D. Thesis, University College Dublin, National University of Ireland.

Irish Hydrodata Ltd., 1994. Environmental Survey of Howth Outfall, Technical Report 716/94. Prepared for Dublin Corporation, Civic Offices, Wood Quay, Dublin.

Jiang, J., Fissel, D.B., Topham, D., 2003. 3D numerical modeling of circulations associated with a submerged buoyant jet in a shallow coastal environment. Estuarine, Coastal and Shelf Science 58, 475-486.

Jirka, G., 2004. Integral model for turbulent buoyant jets in unbounded stratified flows. Part I: Single round jet. Environmental Fluid Mechanics 4, 1-56. 
Jirka, G.H., 2006. Integral model for turbulent buoyant jets in unbounded stratified flows part 2: Plane jet dynamics resulting from multiport diffuser jets. Environmental Fluid Mechanics 6, 43-100.

Jovanovic, B., Longmore, C., O’Leary, A., Mariani, S., 2007. Fish community structure and distribution in a macro-tidal inshore habitat in the Irish Sea. Estuarine, Coastal and Shelf Science 75, 135-142.

Kashefipour, S.M., Lin, B., Falconer, R.A., 2006. Modelling the fate of faecal indicators in a coastal basin. Water Research 40, 1413-1425.

Kashefipour, S.M., Lin, B., Harris, E., Falconer, R.A., 2002. Hydro-environmental modelling for bathing water compliance of an estuarine basin. Water Research 36, 1854-1868.

Kolluru, V.S., Buchak, E.M., Brinkmann, P.E., 2003. Hydrodynamic modeling of coastal LNG cooling water discharge. Journal of Energy Engineering 129, 16-31.

Korotenko, K.A., Mamedov, R.M., Kontar, A.E., Korotenko, L.A. (Eds.), 2004. Particle Tracking Method in the Approach for Prediction of Oil Slick Transport in the Sea: Modelling Oil Pollution Resulting from River Input, 1-4 ed. Elsevier, pp. 159170.

Langford, T., 1990. Ecological Effects of Thermal Discharges.

Lehfeldt, R., Bloss, S., 1988. Algebraic turbulence model for stratified tidal flows. In: Dronkers, J., Leussen, W. (Eds.), Physical Processes in Estuaries. Springer-Verlag, pp. 278-291.

Lesser, G.R., Roelvink, J.A., van Kester, J.A.T.M., Stelling, G.S., 2004. Development and validation of a three-dimensional morphological model. Coastal Engineering 51, 883-915.

Liu, W.-C., Kuo, J.-T., Young, C.-C., Wu, M.-C., 2007. Evaluation of marine outfall with three-dimensional hydrodynamic and water quality modeling. Environmental Modeling and Assessment 12, 201-211.

Liu, Y., Ma, L.M., Fang, H.H.P., Gao, T.Y., Xu, Z.X., Wang, Y.C., Jing, Z.G. (Eds.), 2003. Reuse of an Aerobically Treated Wastewater Effluent for the Removal of $\mathrm{SO}_{2}$ in the Flue Gas, third ed. IWA Publishing, pp. 101-107.

Lowe, S.A., Schuepfer, F., Dunning, D.J., 2009. Case study: three-dimensional hydrodynamic model of a power plant thermal discharge. Journal of Hydraulic Engineering 135, 247-256.

Ma, S.W.Y., Kueh, C.S.W., Chiu, G.W.L., Wild, S.R., Yip, J.Y., 1998. Environmental Management of coastal cooling water discharges in Hong Kong. In: Proceedings of the 19th Biennial Conference of the International Association on Water Quality. Part 1 (of 9), Elsevier Ltd, Vancouver, Canada, pp. 267-274.

Mancini, J.L., 1978. Numerical estimates of coliform mortality rates under various conditions. Journal of the Water Pollution Control Federation 50, 2477-2484.

Mansfield, M., 1992. Dublin Bay Water Quality Management Plan: Field Studies of Currents and Dispersion. Technical Report 3, Environmental Research Unit, Ireland.

Marcos, F., Janin, J.M., Teisson, C., 1997. Three-dimensional finite element modelling of thermal and chlorine discharges of a maritime nuclear power plant. In: Proceedings of the 27th Congress of the International Association of Hydraulic Research, IAHR. Part D, ASCE, San Francisco, CA, USA, pp. 329-334.

Martinez-Arroyo, A., Abundes, S., Gonzalez, M.E., Rosas, I., 2000. On the influence of hot-water discharges on phytoplankton communities from a coastal zone of the Gulf of Mexico. Water, Air, and Soil pollution 119, 209-230.

Miyake, Y., Kimura, S., Kawamura, T., Horii, T., Kurogi, H., Kitagawa, T., 2009. Simulating larval dispersal processes for abalone using a coupled particle- tracking and hydrodynamic model: implications for refugium design. Marine Ecology Progress Series 387, 205-222.

Mohsen, M.S., 2004. Treatment and reuse of industrial effluents: case study of a thermal power plant. Desalination 167, 75-86.

Mozetix, P., Malacic, V., Turk, V., 2008. A case study of sewage discharge in the shallow coastal area of the Northern Adriatic Sea (Gulf of Trieste). Marine Ecology 29, 483-494.

Munk, W., Anderson, E.R., 1948. Notes on the theory of the thermocline. Journal of Marine Research 3, 276-295.

Nezu, I., Nakagawa, H., 1993. Turbulence in Open-Channel Flows.

Nicholson, S., Hui, Y.H., Lam, P.K.S., 2011. Pollution in the coastal waters of Hong Kong: case studies of the urban Victoria and Tolo Harbours. Water and Environment Journal 25, 387-399.

O’Boyle, S., McDermott, G., Wilkes, R., 2009. Dissolved oxygen levels in estuarine and coastal waters around Ireland. Marine Pollution Bulletin 58, 1657-1663.

O'Higgins, T.G., Wilson, J.G., 2005. Impact of the river Liffey discharge on nutrient and chlorophyll concentrations in the Liffey estuary and Dublin Bay (Irish Sea). Estuarine, Coastal and Shelf Science 64, 323-334.

Park, K., Kuo, A.Y., 1994. Numerical modeling of advective and diffusive transport in the Rappahannock Estuary, Virginia. In: Proceedings of the 3rd International Conference on Estuarine and Coastal Modeling III, ASCE, Oak Brook, IL, USA, pp. 461-474.

Perianez, R., Caravaca, F., 2010. A set of rapid-response models for pollutant dispersion assessments in southern Spain coastal waters. Marine Pollution Bulletin 60, 1412-1422.

Signell, R.P., Jenter, H.L., Blumberg, A.F., 2000. Predicting the physical effects of relocating Boston's sewage outfall. Estuarine, Coastal and Shelf Science 50, 5972.

Syed Mohamed, H.E., Krishnamoorhy, R., Venugopalan, V.P., Bukhari, A.S., Hameed P.S., 2010. Thermal tolerance studies in wedge clam donax cunetaus (Bivalviadonacidae) in relation to thermal discharge from Madras atomic power station, Kalpakkam (East coast of India). Ecology, Environment and Conservation 16 175-179.

Van Den Hende, S., Vervaeren, H., Desmet, S., Boon, N., 2011. Bioflocculation of microalgae and bacteria combined with flue gas to improve sewage treatment. New Biotechnology 29, 23-31.

Vijay, R., Khobragade, P.J., Sohony, R.A., 2010. Water quality simulation of sewage impacts on the west coast of Mumbai, India. Water Science and Technology 62, 279-287.

Viollet, P., 1988. On the numerical modeling of stratified flows. In: Dronkers, J. Leussen, W. (Eds.), Physical Processes in Estuaries. Springer-Verlag, pp. 257277.

Warren, I.R., Bach, H.K., 1992. MIKE 21. A modelling systems for estuaries, coastal waters and seas. Environmental Software 7, pp. 229-229.

Wilson, J.G., 2005. Diffuse inputs of nutrients to Dublin Bay. Water Science and Technology 51, 231-237.

Wilson, J.G., Brennan, M., Murray, A., 2002. Particulate inputs to Dublin Bay and to the South Lagoon, Bull Island. Hydrobiologia 475-476, 195-204.

Wu, J., Buchak, E.M., Edinger, J.E., Kolluru, V.S., 2001. Simulation of cooling-water discharges from power plants. Journal of Environmental Management 61, 7792. 